\title{
PKM Penguatan Regimen Terapeutik Penderita Diabetes Mellitus dengan Senam DM, Konseling, Pemeriksaan Sensasi Kaki dan Diabetic Neuropathy Symptomps
}

\author{
Dyah Wiji Puspita Sari, Retno Setyawati, Ahmad Ikhlasul Amal, Suyanto, Muh. Abdurrouf, \\ Fitria Endah Janitra, Indah Sri Wahyuni \\ Fakultas Ilmu Keperawatan, Universitas Islam Sultan Agung \\ daiyah_04@yahoo.com
}

Received: $23^{\text {rd }}$ April 2020 | Accepted: 30 $0^{\text {th }}$ November 2020 | Published: 30 $0^{\text {th }}$ January 2021

\begin{abstract}
Key word:

therapeutic

regimen;

diabetes;

neuropathy

diabetic

\section{Kata Kunci}

Regimen

terapeutik;

diabetes;

neuropati

diabetik

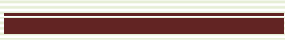

Complications from diabetes mellitus can be prevented by strengthening the therapeutic regimen of people with diabetes mellitus. This Community Service Program (PKM) aims to support government programs in handling noncommunicable diseases especially diabetes mellitus through effective community-based strategies to improve the quality of life for people with DM. The targets in this PKM are people with diabetes who are members of the prolanist program under the auspices of the Bangetayu Community Health Center in Semarang. The method of implementing PKM is the empowerment method which is carried out through several stages, namely socialization, implementation of activities, as well as monitoring and evaluation. The results in this program are increased knowledge of people with DM in understanding the concept of physical activity training for DM patients and diabetic neuropathy symptoms and their prevention, increased ability to practice physical activity with DM exercises from $10 \%$ to $80 \%$, participants with diabetes know the results of examination of decreased foot sensation and the appearance of signs symptoms of diabetic neuropathy. The PKM follow-up is that people with diabetes can check their feet sensation and enhance the therapeutic regimen periodically to prevent DM complications. It is hoped that they can maintain physical activity training.

\section{Abstrak}

Komplikasi dari diabetes melitus dapat dicegah dengan penguatan regimen terapeutik penderita diabetes mellitus. Program Pengabdian Kepada Masyarakat (PKM) ini bertujuan mendukung program pemerintah dalam penanganan penyakit tidak menular khususnya diabetes mellitus melalui strategi yang efektif berbasis masyarakat untuk meningkatkan kualitas hidup penderita DM. Sasaran dalam PKM ini adalah diabetisi yang tergabung dalam program prolanis di bawah binaan Puskesmas Bangetayu Kota Semarang. Metode pelaksanaan PKM ini yaitu metode empowerment yang dilaksanakan melalui beberapa tahapan yaitu sosialisasi, pelaksanaan kegiatan, serta monitoring dan evaluasi. Hasil dalam program ini adalah meningkatnya pengetahuan masyarakat penderita DM dalam memahami konsep latihan aktifitas fisik pasien DM serta neuropati diabetic symstoms dan pencegahannya, meningkatnya kemampuan praktik aktifitas fisik dengan senam DM dari $10 \%$ menjadi $80 \%$, peserta diabetisi mengetahuihasil pemeriksaan penurunan sensasi kaki dan munculnya tanda gejala neuropati diabetik. Tindak lanjut PKM ini adalah diabetisi dapat melakukan pemeriksaan sensasi kaki dan peningkaan regimen terapeutik secara berkala untuk mencegah komplikasi DM diharapkan dapat mempertahankan latihan akifitas fisik.
\end{abstract}




\section{PENDAHULUAN}

Diabetes melitus (DM) merupakan salah satu dari penyakit degenaratif yang dapat menjadikan ancaman serius bagi kehidupan individu. Penyakit ini sering disebut dengan The Great Imitator, yakni penyakit yang menyerang semua organ tubuh manusia dan dapat menimbulkan berbagai macam keluhan bagi penderita.

Estimasi 425 juta orang dewasa (20 -79 tahun) hidup dengan diabetes, diperkirakan pada tahun 2045 kondisi ini akan meningkat hingga 629 juta, usia terbesar penderita diabetes antara 40 dan 59 tahun. Proporsi individu dengan diabetes tipe 2 meningkat di beberapa negara, sekitar 352 juta orang berisiko menderita diabetes tipe $2,79 \%$ orang dewasa penderita diabetes berada di negara-negara dengan pendapatan rendah dan menengah (Ogurtsova et al., 2017). Prevalensi penderita diabetes di Indonesia terdapat kecenderungan meningkat yaitu dari 5.7\% (2007) menjadi $6.9 \%$ (2013). Tahun 2015 Indonesia menempati urutan ke tujuh dunia dengan perkiraan jumlah penderita diabetes sebesar 10 juta orang (Ogurtsova et al., 2017)

Diabetes dapat dicegah atau kejadiannya dapat ditunda dengan tatalaksana pengobatan yang optimum, diabetes dapat dikontrol dan orang dengan diabetes dapat berumur Panjang dan hidup sehat (Oktorina et al., 2019). Pengelolaan diabetes melitus memiliki dua tujuan yaitu jangka pendek dan jangka panjang. Tujuan jangka pendek adalah menghilangkan keluhan/gejala DM serta mempertahankan rasa nyaman dan sehat, sedangkan tujuan jangka panjang yaitu mencegah penyulit/komplikasi baik makroangiopati, mikroangiopati maupun neuropati dengan tujuan akhir menurunkan morbiditas dan mortalitas DM (Hestiana, 2017).

Komplikasi dari diabetes melitus dapat dicegah dengan melakukan pengontrolan yang terapeutik dan teratur melalui perubahan gaya hidup pasien DM yang tepat dan konsisten. Pengontrolan diabetes melitus diantaranya adalah pembatasan diet, peningkatan aktivitas fisik yang salah satunya melalui senam DM, regimen pengobatan yang tepat, pengontrolan metabolik secara teratur melalui pemeriksaan laboratorium serta melakukan screening terhadap risiko neuropati diabetic (Wilayah \& Bukateja, 2010).

Pencegahan komplikasi dan kegiatan controlling pada penderita diabetes dapat dilakukan dengan memberikan pengetahuan melalui edukasi yang tepat. Peran perawat sebagai educator yakni memberikan pendidikan kesehatan sehingga diharapkan masyarakat memahami dan mengambil keputusan mengenai kondisi kesehatannya (Siwi Handayani et al., 2013). 
Tujuan dari PKM ini adalah memberikan skill dan pengetahuan yang tepat kepada para penderita DM dalam melakukan perawatan terhadap penyakitnya serta memberikan layanan kesehatan kepada penderita DM agar pada akhirnya kualitas kesehatan penderita DM tersebut meningkat.

Salah satu wilayah binaan Puskesmas Bangetayu yaitu Kelurahan Penggaron Lor. Jumlah penduduk Kelurahan Penggaron Lor adalah 4.097 orang, dengan proporsi laki-laki dan wanita hampir sama dan jumlah anak kurang lebih 2 setiapkeluarganya (Data Monografi Kelurahan Penggaron Lor, 2010). Berdasarkan jumlah penduduk tersebut, saat ini terdapat penderita DM sebanyak 26 orang dalam 2 RW yang perlu mendapatkan perhatian terhadap kondisi kesehatannya.

Pada wilayah binaan Puskesmas Bangetayu ini terdapat komunitas diabetisi yang tergabung dalam kegiatan prolanis. Tiap bulan secara rutin terdapat kegiatan prolanis, tetapi belum pernah dilaksanakan senam DM. Senam yang dilaksanakan oleh penderita DM hanyalah senam biasa. Hal ini menjadikan penderita DM kurang mendapatkan jenis terapi yang tepat untuk olahraga atau aktivitas fisik pada penderita DM.

Berdasarkan dari paparan di atas, komunitas diabetisi pada program prolanis
Puskesmas Bangetayu layak menjadi mitra dalam pelaksanaan pengabdian kepada masyarakat yang berjudul PKM penguatan regimen terapeutik penderita DM di Puskesmas Bangetayu dengan senam DM, konseling DM, pemeriksaan sensasi kaki dan diabetic neuropathy symptomps.

\section{METODE}

Metode dalam pelaksanaan PKM ini menggunakan metode empowerment. Pemberdayaan masyarakat menjadi suatu proses dalam pembangunan masyarakat dengan bentuk penggalian kemampuan, kompetensi, daya pikir dan kreatifitas dalam rangka meningkatkan kualitas hidup masyarakat tersebut (Sjattar \& Yusuf, 2019). Strategi empowerment atau pemberdayaan dilaksanakan dengan memberdayakan masyarakat anggota prolanis yang dilakukan dalam 3 ( tiga ) tahapan, yaitu (1) Sosialisasi,

Pelaksanaan kegiatan, serta (3) Monitoring dan Evaluasi. Penggunaan 3 metode ini efektif digunakan untuk memberikan pendampingan dalam penguatan regimen terapeutik para diabetisi. Kegiatan pendampingan yang dilakukan oleh TIM pengabdian ini menjadi cara yang digunakan untuk memberdayakan para diabetisi sehingga tujuan dari pengabdian masyarakat tercapai. 
Metode sosialisasi dilaksanakan untuk memberikan pemahaman mengenai program, alur, dan tahapan program PKM, serta pemberian pemahaman tentang materi yang harus dipahami terlebih dahulu yaitu tentang konsep dan prinsip dalam aktifitas fisik pasien diabetes mellitus khususnya senam diabetes mellitus, konsep, manfaat, dan cara pemeriksaan sensasi kaki dan diabetic neuropathy symptomps (DNS).

Metode pelaksanaan kegiatan ini dilakukan dengan menjalin kerjasama dengan pusat pelayanan kesehatan terdekat dengan masyarakat yaitu Puskesmas. Kerjasama dengan Puskesmas dilaksanakan dalam rangka melaksanakan tanggungjawab bersama untuk menyelenggarakan pembangunan kesehatan dan membina peran serta masyarakat untuk meningkatkan kualitas hidup masyarakat.

Puskesmas pada kelompok masyarakat yang tergabung dalam komunitas diabetisi program prolanis digerakkan untuk mengikuti kegiatan PKM ini. Terdapat 26 diabetisi yang mengikuti kegiatan PKM ini. Pada pelaksanaan kegiatan, para diabetisi diajak untuk mengikuti berbagai kegiatan regiment terapiutik bagi penderita DM diantaranya adalah pengaturan aktivitas fisik seperti senam DM, Konseling, Pemeriksaan Sensasi Kaki dan Diabetic Neuropathy Symptomps.
Pada tahap pelaksanaan, senam DM dilakukan bersama instruktur senam DM yang dilaksanakan dengan demonstrasi secara langsung. Hal ini dilaksanakan dengan tujuan para diabetisi dapat melakukan senam DM dengan benar secara mandiri. Selain senam DM, kegiatan konseling dan pemeriksaan Sensasi Kaki dan Diabetic Neuropathy Symptomps dilaksanakan oleh tenaga kesehatan yang berasal dari TIM PKM ini.

Pada tahap monitoring dan evaluasi dilaksanakan setiap bulan sekali tiap dilaksanakan kegiatan prolanis.. Pelaksanaan monev dilaksanakan dengan cara diabetisi yang mengikuti program prolanis dikumpulkan untuk dilakukan monev terhadap pelaksanaan kegiatan selama kegiatan regiment terapiutik diabetisi berlangsung. Apabila dalam proses pelaksanaan kegiatan ditemukan kendala oleh para diabetisi, tim pengabdian memberikan pembinaan dan penguatan terhadap masalah yang ditemukan.

\section{HASIL}

Pelaksanaan PKM Penguatan Regimen Terapeutik Penderita Diabetes Mellitus dengan Senam DM, Konseling, Pemeriksaan Sensasi Kaki dan Diabetic Neuropathy Symptomps dilaksanakan pada anggota prolanis di Puskesmas Bangetayu Kota Semarang. Kegiatan ini dilaksanakan 
oleh 7 orang dosen dari Fakultas Ilmu Keperawatan Unissula dan diikuti oleh 26 orang diabetisi.

Pelaksanaan kegiatan PKM Penguatan Regimen Terapeutik Penderita Diabetes Mellitus dengan Senam DM, Konseling, Pemeriksaan Sensasi Kaki dan Diabetic Neuropathy Symptomps ini telah dilaksanakan melalui tahapan sosialisasi, pelaksanaan kegiatan, dan monitoring dan evaluasi yang terorganisir.

Melalui metode sosialisasi yang telah diterapkan memberikan hasil bahwa para diabetisi memahami tentang pemeriksaan sensasi kaki dan peningkaan regimen terapeutik secara berkala untuk mencegah komplikasi DM, kewaspadaan akan komplikasi DM, pentingnya melakukan kunjungan rutin atau konseling ke puskesmas untuk penguatan terapi lanjutan, dan prinsip aktivitas fisik yang sebaiknya dilakukan para diabetisi, serta arti penting dan gerakan-gerakan senam diabetes mellitus.

Sebelum pemberian sosialisasi para peserta di berikan pre test tentang materimateri pengabdian masyarakat yang terdiri dari prinsip aktivitas fisik diabetisi, senam DM, konseling, pemeriksaan sensasi kaki dan diabetic neuropathy symptomps dan komplikasi DM. Dilanjutkan dengan pemberian materi dan diakhiri dengan post test. Dengan adanya pre test diharapkan menjadi tolok ukur untuk melihat kemampuan awal diabetisi tentang regiment terapiutik pasien DM.

Pada hasil pre test menunjukkan bahwa tingkat pengetahuan diabetisi tentang regiment terapiutik pasien DM 10\%, setelah di post test meningkat menjadi $80 \%$. Hal ini menunjukkkan pentingnya sosialisasi untuk meningkatkan pemahaman diabetisi.

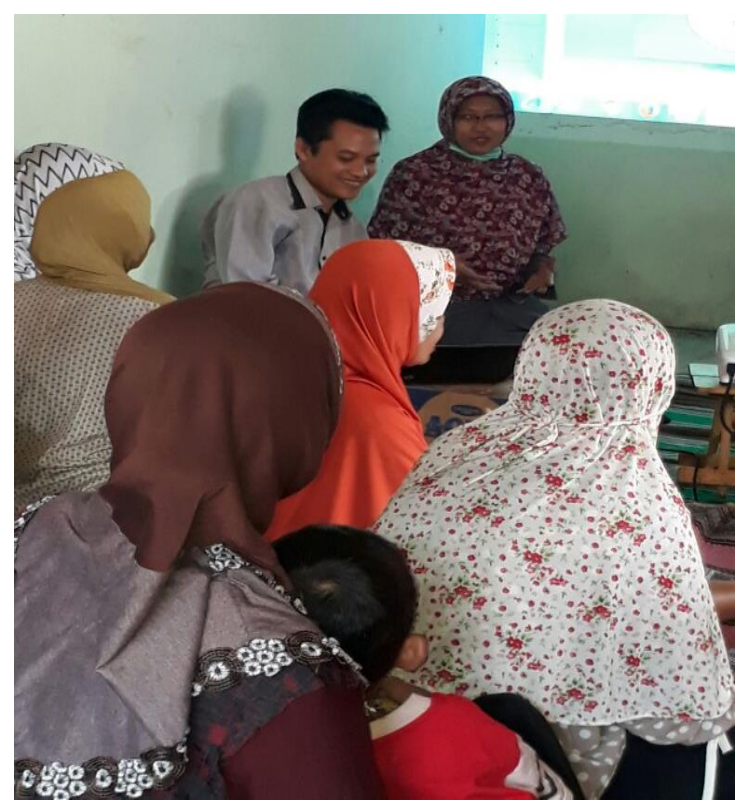

Gambar 1. Pelaksanaan Sosialisasi kepada anggota prolanis.

\section{PEMBAHASAN}

Pelaksanaan kegiatan PKM ini dilaksanakan dengan bekerjasama dengan pusat pelayanan kesehatan terdekat dengan masyarakat yaitu Puskesmas Bangetayu. Koordinator prolanis yang diketuai oleh seorang dokter membantu tm pengabdian dalam mengkoordinasikan para peserta prolanis. Peran dari puskesmas sangat mendukung keberhasilan kegiatan PKM ini. 
Puskesmas merupakan sebuah unit pelaksana teknis dari Dinas Kesehatan Kabupaten atau Kota yang memiliki tanggungjawab dalam menyelenggarakan pembangunan kesehatan di suatu wilayah kesehatan. Puskesmas menjadi pusat pengembangan kesehatan masyarakat dalam membina peran serta masyarakat juga memberikan pelayanan secara menyeluruh dan terpadu (Ulumiyah, 2018).

Puskesmas mempunyai wewenang dan tanggung awab atas pemeliharaan kesehatan masyarakat dalam wilayah kerjanya. Pelayanan kesehatan yang diberikan puskesmas adalah pelayanan kesehatan menyeluruh yang meliputi pelayanan: kuratif (pengobatan), preventif (upaya pencegahan), promotif (peningkatan kesehatan), dan rehabilitatif (pemulihan kesehatan).

Pelaksanaan kegiatan ini diawali dengan pendampingan dalam mendemonstrasikan senam DM yang dipimpin oleh instrukstur senam DM dari TIM pengabdi. Para peserta senam tampak sangat antusias. Para peserta menyampaikan bahwa sebelumnya belum pernah mendapatkan senam khusus Diabetes Mellitus. Selama ini senam yang dilakukan adalah senam biasa yang di pimpin oleh instruktur senam tim prolanis. Berdasarkan hasil wawancara dengan instruktur senam peserta prolanis, di dapatkan data bahwa instruktur senam tersebut belum pernah tahu tentang senam DM. Kegiatan hari ini memberikan arahan kepada instruktur senam tersebut untuk senam-senam ke depan akan mengaplikasikan senam DM, sehingga lebih tepat diberikan pada peserta polanis yang sebagian besar merupakan diabetisi (Amalia et al., 2020).

Melalui pelatihan senam DM ini diharapkan para peserta prolanis dapat melaksanakan senam DM ini secara mandiri dan teratur di rumah masing-masing. menyebutkan bahwa pelatihan bertujuan untuk mengembangkan keahlian dan dan kemampuan individu untuk memperbaiki kinerja, membiasakan pegawai dengan sistim, prosedur dan metode kerja yang baru, serta membantu pegawai dan pendatang baru menjadi terbiasa dengan persyaratan pekerjaan tertentu dan persyaratan organisasi.

Pemberian pendidikan kesehatan dan penyuluhan pada hakikatnya merupakan suatu kegiatan untuk menyampaikan pesan kepada masyarakat, kelompok, atau individu dengan harapan kelompok tersebut mendapatkan pengetahuan tentang kesehatan yang lebih baik. Hal ini menunjukkan bahwa informasi yang baik mengenai kesehatan akan menimbulkan kesehatan yang baik pula (Simamora, 2019). 


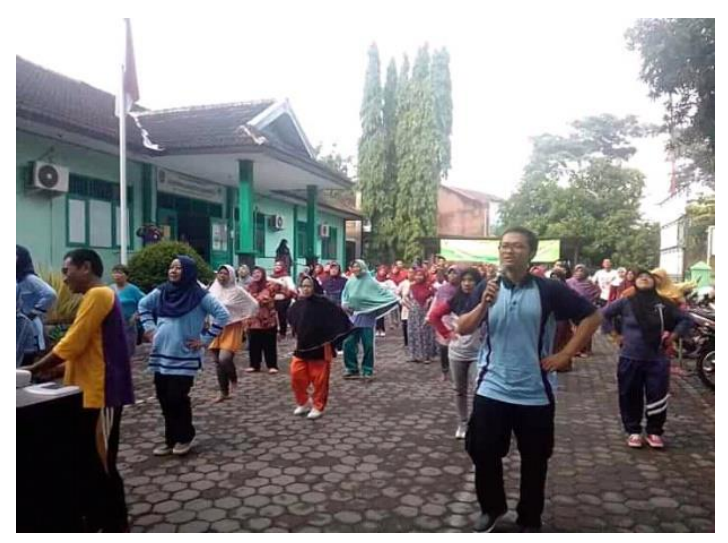

Gambar 2. Pendampingan pada kegiatan senam DM

Selain pelaksanaan yang berfokus pada senam DM, kegiatan pengabdian dilanjutkan dengan pemeriksaan Sensasi Kaki dan Diabetic Neuropathy Symptomps. Hal ini sangat penting dilakukan karena salah satu komplikasi utama dari DM yang mengakibatkan tingginya angka morbiditas pada penderita DM adalah neuropati diabetika (Indriani et al., 2019). Neuropati diabetik adalah terdapatnya tanda dan gejala dari disfungsi saraf tepi pada pasien DM tanpa ada penyebab lainnya (Hidayat \& Nurhayati, 2014). Prevalensi neuropati diabetik terjadi $60-70 \%$ pada pasien DM type I dan II (. Usia 50 tahun ke atas merupakan usia yang paling sering dijumpai mengalami neuropati (Mildawati et al., 2019).

Neuropati ditandai dengan kaki menjadi terasa dingin, nyeri yang khas seperti nyeri terbakar, mati rasa atau berkurangnya sensasi sensori dari stimulus sentuhan, getaran, nyeri dan suhu, rasa kering, kadang sakit pada kaki dimana pulsasi arteri masih teraba. Hal ini menjadikan deteksi dini neuropati diabetik menjadi sangat penting bagi pendrita DM. Instrumen yang digunakan untuk mengukur sensasi kaki pada penderita DM yang beresiko neuropati yakni Siemens Weinstein Monofilament 10.

Adapun hasil yang didapatkan yaitu mayoritas penderita DM yang mengikuti pemeriksaan tersbut ditemukan sebanyak 19 penderita masih memiliki sensasi kaki yang baik dikedua sisi kaki (kanan dan kiri). Adapun skor DNS atau diabetic neuropatic symptom mayoritas atau sejumlah 18 peserta tidak memiliki tanda atau symptompt neuropati diabetic. Selain dilakukan pemeriksaan tersbut, peserta juga mendapatkan pemeriksaan tekanan darah gratis serta pemberian penyuluhan kesehatan tentang perawatan neuropati diabetic.

Peserta yang berpartisipasi dalam penguatan regimen terapeutik tersebut terlihat sangat antusias. Hal ini dikarenakan masyarakat merasa bahwa pemeriksaan dan pemberian materi yang disampaikan sangat bermanfaat. Peserta mengikuti pelatihan dari awal penyampaian materi sampai pemeriksaan selesai dilakukan. 


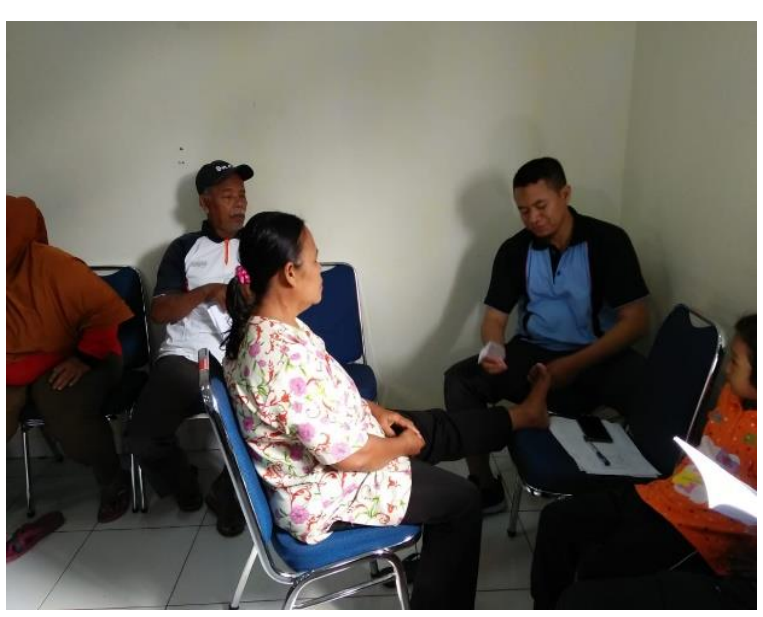

Gambar 3. Pendampingan pada kegiatan pemeriksaan Sensasi Kaki dan Diabetic Neuropathy Symptomps

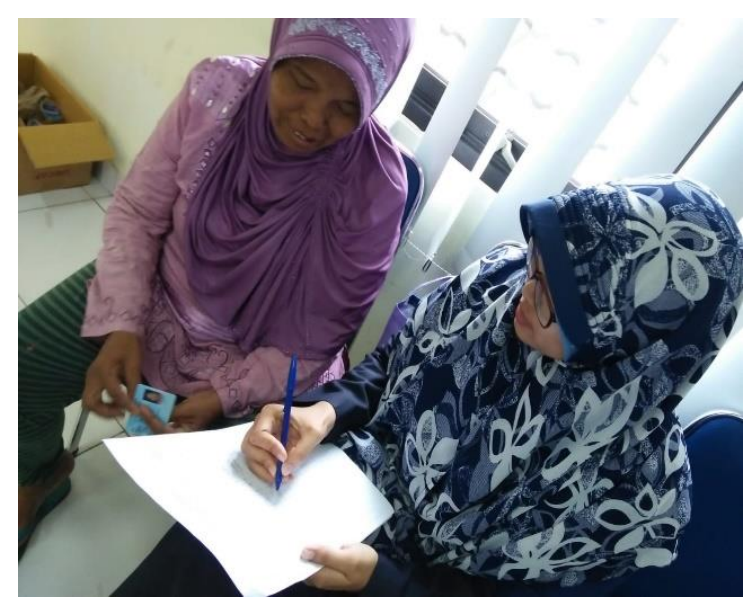

Gambar 4. Pendampingan pada kegiatan konseling

Pada metode monitoring dan evaluasi dilaksanakan setiap bulan sekali pada saat kegiatan prolanis berjalan dengan cara seluruh peserta prolanis dan pembina prolanis dikumpulkan untuk dilakukan monev terhadap pelaksanaan kegiatan. Monitoring dan evaluasi merupakan sebuah proses yang berkesinambungan meliputi pengumpulan data, proses dan pemilihan informasi mengenai implementasi proyek, progress yang dicapai pada proyek tersebut sampai kepada dampak dan efek dari adanya proyek tersebut (Aryanti et al., 2015). Monitoring dan evaluasi diperlukan untuk melihat tingkat keberhasilan dan ketercapaian tujuan dan manfaat programprogram pembangunan Kota Semarang.

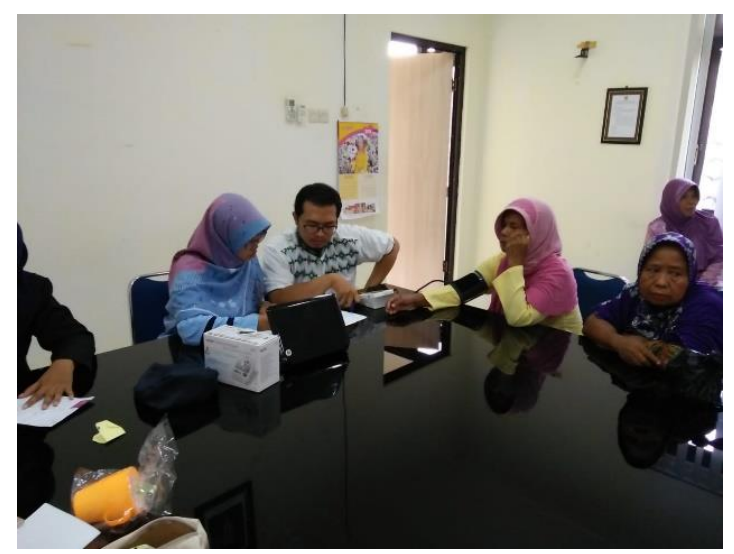

Gambar 5. Kegiatan Monev

Berdasarkan hasil monitoring evaluasi didapatkan hasil bahwa peserta prolanis sudah hafal gerakan-gerakan senam DM dan istruktur senam sudah memulai senamnya dengan senam DM. selain itu terdapat peningkatan pada kualitas hidup diabetisi yang ditunjukkan dengan hasil pengontrolan kadar gula darah dan tekanan darah sebagian besar diabetisi terkontrol dengan baik. Hal ini menunjukkan bahwa PKM Penguatan Regimen Terapeutik Penderita Diabetes Mellitus dengan Senam DM, Konseling, Pemeriksaan Sensasi Kaki dan Diabetic Neuropathy Symptomps memiliki peran yang penting dalam meningkatkan kualitas hidup diabetisi.

Keunggulan Program PKM Penguatan Regimen Terapeutik Penderita Diabetes Mellitus dengan Senam DM, 
Konseling, Pemeriksaan Sensasi Kaki dan

Diabetic Neuropathy Symptomps yaitu menjadi strategi yang efektif dan terintegrasi, berbasis masyarakat melalui kerjasama lintas program dan lintas sektor untuk meningkatkan kualitas hidup masyarakat yang menderita Diabetes Mellitus (Sucipto, 2014). Pada Pelaksanaan kegiatan pengabdian ini tidak dialami kesulitan yang signifikan karena diabetisi dan Puskesmas mampu bekerjasama dengan sangat baik.

Faktor pendukung keberhasilan acara meliputi materi yang disampaikan secara jelas didukung dengan penggunaan media pembelajaran yang sesuai seperti power point, video, leaflet serta peragaan senam DM langsung oleh instruktur. Sehingga peserta langsung mempraktekkan materi yang didapat. Pemateri serta fasilitator juga membantu para peserta pelatihan sampai peserta benar-benar memahami dan dapat melakukan praktek atau latihan senam DM dengan benar. Pendukung lainnya yaitu keterlibatan langsung dari pihak puskesmas bangetayu wetan yang sangat mendukung kegiatan tersebut dengan baik.

Pihak puskesmas menyampaikan kegiatan semacam ini perlu dipertahankan agar penderita DM di wilayah puekesmas ini secara umum dapat meningkatkan kualitas hidupnya. Kegiatan pengabidan masyarakat ini berlangsung dengan lancar dan tanpa ada kendala yang berarti dari awal sampai akhir.

\section{SIMPULAN}

Pengabdian masyarakat PKM Penguatan Regimen Terapeutik Penderita Diabetes Mellitus dengan Senam DM, Konseling, Pemeriksaan Sensasi Kaki dan Diabetic Neuropathy Symptomps dapat disimpulkan bahwa berbagai penguatan regimen terapiutik pada penderita DM melalui komunitas Diabetisi dibawah binaan Puskesmas Bangetayu dapat meningkatkan pengetahuan masyarakat penderita DM dalam memahami konsep latihan aktifitas fisik pasien DM.

Meningkatnya kemampuan praktik aktifitas fisik dengan senam DM dari 10\% menjadi $80 \%$, meningkatnya pengetahuan masyarakat penderita DM dalam memahami neuropati diabetic dan pencegahannya, serta berdasarkan hasil pemeriksaan kesehatan oleh tim PKM dapat menunjukkan kepada para penderita DM bahwa pada tubuhnya terdapat resiko adanya penurunan sensasi kaki dan munculnya tanda gejala neuropati diabetik dari $0 \%$ menjadi $100 \%$.

\section{SARAN}

Program kegiatan PKM Penguatan Regimen Terapeutik Penderita Diabetes Mellitus dengan Senam DM, Konseling, 
Pemeriksaan Sensasi Kaki dan Diabetic Neuropathy Symptomps ini masih berada dalam lingkup yang kecil tetapi telah memberikan dampak yang cukup baik dalam perawatan mandiri diabetisi di rumah, sehingga diharapkan menjadi inisiasi awal bagi diabetisi untuk dapat melakukan pemeriksaan sensasi kaki dan peningkaan regimen terapeutik secara berkala untuk mencegah komplikasi DM dan meningkatkan kewaspadaan akan komplikasi DM. Diharapkan pasien diabetes dapat mempertahankan latihan akifitas fisik (senam DM) ini secara berkelanjutan dan melakukan kunjungan rutin ke puskesmas untuk penguatan terapi lanjutan.

\section{UCAPAN TERIMA KASIH}

Ucapan rasa terima kasih yang sebesar-besarnya penulis ucapkan kepada Lembaga Penelitian dan Pengabdian Masyarakat Unissula yang telah membantu dalam menunjang pelaksanaan pengabdian masyarakat ini melalui Hibah Pengabdian Masyarakat hingga selesai dengan baik

\section{DAFTAR PUSTAKA}

Amalia, A. W., Gayatri, P. R., \& Tuna, H. (2020). Pengaruh Senam GITA terhadap IMT dan HbA1C Pada Lansia dengan Diabetes Melitus Effects of GITA Gymnastics on BMI and $\mathrm{HbA1C}$ in
Elderly with Diabetes Mellitus. Faletehan

Health Journal, 7(3), 155-161.

Aryanti, T., Supriyono, S., \& Ishaq, M. (2015). Evaluasi Program Pendidikan Dan Pelatihan. Jurnal Pendidikan Nonformal, 10(2), 1-13.

Hestiana, D. W. (2017). Faktor-Faktor yang Berhubungan Dengan Kepatuhan dalam Pengelolaan Diet pada Pasien Rawat Jalan Diabetes Mellitus Tipe 2 di Kota Semarang. Journal of Health Education, 2(2), 138-145. https://doi.org/10.1080/10556699.1994.10 603001

Hidayat, A. R., \& Nurhayati, I. (2014). Perawatan Kaki Pada Penderita Diabetes Militus di Rumah. Jurnal Permata Indonesia, 5(2), 49-54. http://www.permataindonesia.ac.id/wpcontent/uploads/2015/07/201406.pdf Indriani, S., Amalia, I. N., \& Hamidah, H. (2019). Hubungan Antara Self Care Dengan Insidensi Neuropaty Perifer Pada Pasien Diabetes Mellitus Tipe II RSUD Cibabat Cimahi 2018. Jurnal Ilmu Kesehatan Bhakti Husada: Health Sciences Journal, 10(1), 54-67. https://doi.org/10.34305/jikbh.v10i1.85 Mildawati, Diani, N., \& Wahid, A. (2019). Hubungan Usia, Jenis Kelamin dan Lama Menderita Diabetes dengan Kejadian Neuropati Perifer Diabateik. Caring Nursing Journal, 3(2), 31-37.

Ogurtsova, K., da Rocha Fernandes, J. D., Huang, Y., Linnenkamp, U., Guariguata, L., Cho, N. H., Cavan, D., Shaw, J. E., \& 
Makaroff, L. E. (2017). IDF Diabetes

Atlas: Global estimates for the prevalence of diabetes for 2015 and 2040. Diabetes

Research and Clinical Practice, 128, 4050.

https://doi.org/10.1016/j.diabres.2017.03. 024

Oktorina, R., Wahyuni, A., \& Harahap, E. Y. (2019). Faktor-Faktor Yang Berhubungan Dengan Perilaku Pencegahan Ulkus Diabetikum Pada Penderita Diabetes Mellitus. Real in Nursing Journal, 2(3), 108. https://doi.org/10.32883/rnj.v2i3.570 Simamora, R. H. (2019). Pengaruh Penyuluhan Identifikasi Pasien dengan Menggunakan Media Audiovisual Terhadap Pengetahuan Pasien Rawat Inap. Jurnal Keperawatan Silampari, 3(1), 342-351.

Siwi Handayani, D., Yudianto, K., \&

Kurniawan, T. (2013). Perilaku Self-

Management Pasien Diabetes Melitus

(DM). Jurnal Keperawatan Padjadjaran, $v 1(\mathrm{n} 1), 30-38$.

https://doi.org/10.24198/jkp.v1n1.4

Sjattar, E. L., \& Yusuf, S. (2019). Efektifitas

Pemberdayaan Keluarga Terhadap

Kontrol Metabolik Pada Pasien Diabetes

Melitus Tipe 2. Jurnal Keperawatan

Muhammadiyah, 4(2), 130-136.

http://journal.um-

surabaya.ac.id/index.php/JKM

Sucipto, A. (2014). Efektivitas Konseling DM

dalam Meningkatkan Kepatuhan dan

Pengendalian Gula Darah pada Diabetes

Melitus Tipe 2. IJNP (Indonesian Journal

of Nursing Practices), 1(1), 8-20. https://journal.umy.ac.id/index.php/ijnp/ar ticle/view/637

Ulumiyah, N. H. (2018). Meningkatkan Mutu Pelayanan Kesehatan Dengan Penerapan Upaya Keselamatan Pasien Di Puskesmas. Jurnal Administrasi Kesehatan Indonesia, 6(2), 149. https://doi.org/10.20473/jaki.v6i2.2018.1 49-155

Wilayah, D. I., \& Bukateja, P. (2010). Pengaruh Latihan Fisik; Senam Aerobik Terhadap Penurunan Kadar Gula Darah Pada Penderita Dm Tipe 2 Di Wilayah Puskesmas Bukateja Purbalingga. Nurse Media Journal of Nursing, 1(2), 89-99. https://doi.org/10.14710/nmjn.v1i2.717 
p-ISSN : 2548-8783

e-ISSN : 2548-8791

30 | Journal of Dedicators Community Unisnu Jepara 